\title{
MAD2L2 Gene
}

National Cancer Institute

\section{Source}

National Cancer Institute. MAD2L2 Gene. NCI Thesaurus. Code C116589.

This gene plays a role in both DNA translesion synthesis and the mitotic spindle assembly checkpoint. 